\title{
BHAGAWATIMAH CIDYĀ DEWI: \\ IDENTIFIKASI FIGUR WANITA MENGGENDONG BAYI DALAM PRASASTI CEBONGAN
}

\author{
Kayato Hardani \\ (Balai Pelestarian Peninggalan Purbakala Yogyakarta)
}

\begin{abstract}
Some historical-archaeological remains from Java in $9^{\text {th }}-10^{\text {th }}$ century such as inscriptions have been preserved in good condition. Most of them has been transliterated and documented on systematically corpus or catalogues. The inscriptions which incised on stone or chopper were issued by the king who reigned in Java on that time, usually to commemorate the establishment of a free-hold land or cultivation area. Social-cultural lifehood sometimes reflected from the inscriptions. Only a few can be classified as spell or 'mantra' inscription. Besides old Java writing, human figurines is also described on the the chopper inscription. She is Bhagawatimah Cidya Dewi, divine body with a baby on her arms. There are some correlations found between the description of the figurines with the verbal contents of the inscription.
\end{abstract}

Key words: Prasasti, Hindu, wanita, pemujaan kesuburan, mantra

\section{PENDAHULUAN}

Salah satu koleksi foto di kantor BP3 Yogyakarta yang berasal dari masa Oudheidkundige Dienst berupa foto hitam putih sebuah prasasti tembaga tanpa skala. Foto dengan nomor inventaris OD.2194 tersebut hanya diberi keterangan "koperplaat met vrouwe figuur tjebongan collectie", yang ditulis di sebalik kertas foto. Tidak ada catatan lain mengenai temuan prasasti ini selain diklasifikasikan sebagai temuan dari Distric Mlati, Onderdistric Mlati, Desa Tjebongan. Pada file-file foto lain juga terdapat foto temuan artefaktual dari daerah yang sama seperti yoni, fragmen jaladwara, arca Ganesha, serta beberapa fragmen batu kemuncak. Selain itu juga terdapat foto sisa struktur kaki Candi Cebongan yang masih menunjukkan bentuk denah yang masih sangat bagus. Meski demikian, korelasi kontekstual antara temuan prasasti tembaga, sisa bangunan candi dengan artefak-artefak Hinduistis tersebut belum dapat diketahui dengan jelas. Untuk memudahkan penamaan prasasti, maka di dalam makalah ini digunakan penyebutan 'prasasti Cebongan'.

Pembahasan singkat mengenai prasasti Cebongan ini dijumpai pada dua buah buku katalog dari luar negeri yakni dari Belanda dan Jerman. 
Buku pertama adalah katalog pameran yang diadakan oleh Society of Friends of Asiatic Art yang diadakan di Departement of Asiatic Art, Rijkmuseum Amsterdam pada tanggal 30 April hingga 31 Juli 1988. Katalog ini disusun oleh Pauline Lunsingh Scheurleer dan Marijke J. Klokke dengan judul Divine Bronze : Ancient Indonesian Bronzes from AD 600 to 1600. Katalog ini memuat 114 buah artefak-artefak tembaga yang terdiri dari arca, alat upacara, sejumlah alat rumah tangga, serta lempengan prasasti Cebongan. Di dalam keterangannya, prasasti Cebongan diidentifikasikan sebagai prasasti berisi tentang sima sebagaimana layaknya prasasti dari abad 9-10 Masehi. Lebih jauh disebutkan bahwa prasasti ini merupakan seruan kepada seorang dewi Budhis yang identitasnya belum jelas. Disebutkan pula bahwa prasasti ini temuan dari Jawa Tengah pada tahun \pm 1914 (Scheurleer and Marijke J. Klokke, 1988: 116).

Buku kedua yang memuat keterangan mengenai prasasti Cebongan ini adalah sebuah katalog museum berbahasa Jerman yang disusun oleh Arne Eggebrecht und Eva (1995) dengan judul Versun Kene Konigreische Indonesians. Di dalam keterangan koleksi hanya dideskripsi secara singkat mengenai figur wanita yang menggendong bayi sebagai yaksi Budhis yakni Hariti yang menggendong anaknya, Priyankara (Eggebrecht, 1995: 30).

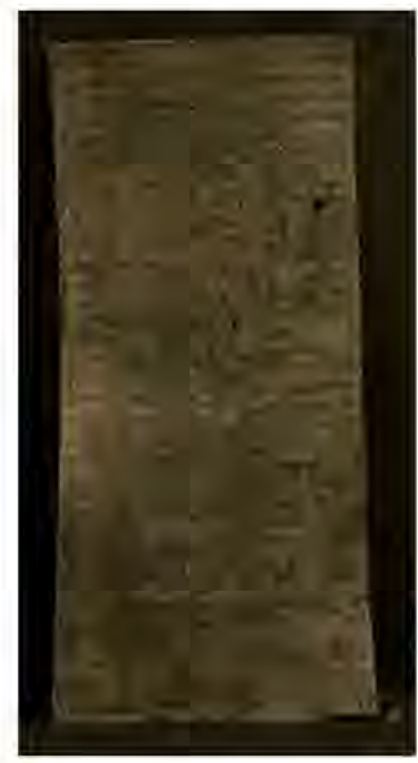

Foto 1.

Foto asli

Prasasti

Cebongan

Berdasar foto

OD 2194

Keberadaan prasasti ini justru tidak teridentifikasi sama sekali dalam literaturliteratur alih bahasa, dan alih aksara prasasti, yang membahas prasasti-prasasti Indonesia khususnya yang berbahasa Jawa Kuna. Literatur-literatur dari masa sebelum tahun 1950-an, seperti Kawi Oorkonden (1875) oleh Cohen Stuart, dan Oud Javaansche Oorkonden selanjutnya disebut OJO (1913) oleh J.L.A Brandes dan N.J Krom juga tidak menyebutnya. Bahkan pada literatur

setelah tahun 1950-an pun tidak memunculkan sama sekali prasasti tembaga dari Cebongan ini, baik pada Prasasti Indonesia selanjutnya disebut PI (1956) oleh J.G de Casparis, serta daftar inventaris seperti Literature of Java (1967) oleh Th.Pigeaud, maupun daftar inventaris yang lebih mutakhir seperti An Inventory of Dated Inscriptions in Java (1982) oleh Kozo Nakada semuanya tidak menyebut mengenai prasasti temuan dari daerah Cebongan. Ketiadaan deskripsi secara keseluruhan atas prasasti ini memunculkan pertanyaan menarik yakni mengapa prasasti ini 
"tidak sempat" masuk di dalam alih aksara dan alih bahasa dalam OJO dan PI? Akibatnya prasasti Cebongan tidak disebut sama sekali di dalam berbagai literatur penting yang sering digunakan sebagai acuan ahli epigrafi Indonesia.

Berdasarkan katalog yang disusun Eggebrecht, diketahui bahwa prasasti Cebongan kini berada di koleksi Kern Institute, Leiden dengan nomor inventaris B-79-I Meskipun demikian dapat dipastikan bahwa prasasti Cebongan ini berasal dari wilayah Yogyakarta yakni desa Cebongan, Kecamatan Mlati, dan ditemukan sekitar tahun 1914 hingga tahun 1920-an. Prasasti Cebongan merupakan satu-satunya prasasti logam dari masa Jawa Kuna yang di dalamnya digambarkan figur seorang manusia. ${ }^{1}$ Figur tersebut adalah seorang wanita menggendong bayi.

Penulisan makalah ini bertujuan untuk mengidentifikasikan figur wanita menggendong bayi yang digambarkan di dalam prasasti ini.

\section{ALIH BAHASA PRASASTI CEBONGAN}

Di dalam makalah ini metode yang digunakan adalah metode penelitian analitis, metode penelitian sintesis dan metode gabungan antara keduanya. Metode analitis dilakukan melalui kritik ekstern (deskripsi prasasti) dan kritik intern (alih aksara dan alih bahasa). Metode sintesis dilakukan melalui fungsi kebudayaan dengan perbandingan struktural terhadap aspekaspek agama, sosial, ekonomi, teknologi, kesenian dan bahasa untuk merekonstruksi masyarakat Indonesia klasik (Dwiyanto, 1993: 7).

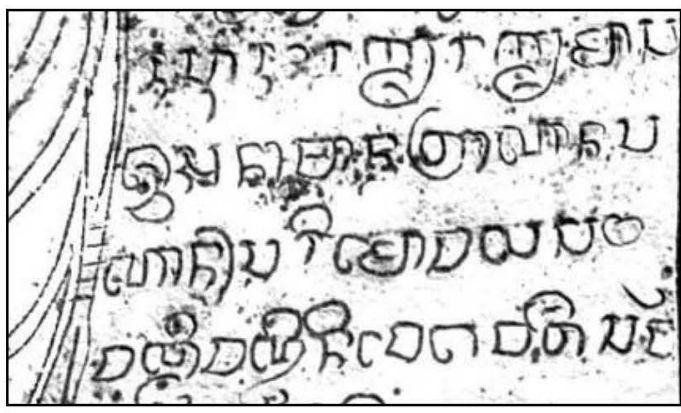

Foto 2.

Gaya aksara yang digunakan di dalam prasasti Cebongan (Sumber: Foto OD 2194 koleksi BP3 Yogyakarta)

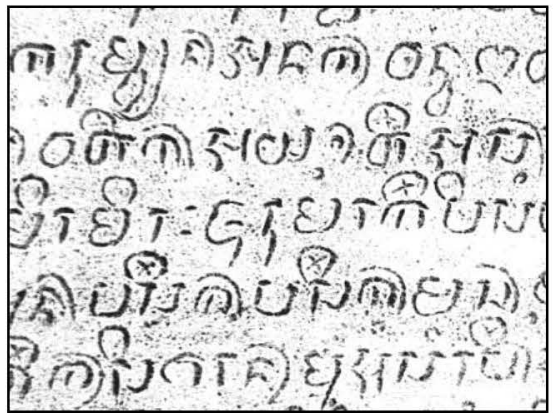

Foto 3 .

Contoh gaya aksara prasasti dari masa Balitung. Prasasti Rumwiga II (BG 637 sisi belakang) (Sumber:Dok. BP3 Yogyakarta)

1 Di dalam prasasti Plalangan juga dijumpai figur manusia memanah, hanya saja figur ini diwujudkan dalam bentuk relief yang dipahatkan di sisi batu yang berbeda dengan pahatan tulisan. Prasasti Plalangan (BG 1396) berbentuk blok batu andesit yang ditemukan pada tahun 1995 di daerah Plalangan, Pendowoharjo, Kabupaten Sleman, Yogyakarta. Lebih lanjut lihat dalam Balai Pelestarian Peninggalan Purbakala Yogyakarta, 2007, Pusaka Aksara Yogyakarta, Alih Aksara dan Alih Bahasa Prasasti Koleksi Balai Pelestarian Peninggalan Purbakala Yogyakarta, Yogyakarta : BP3 Yogyakarta, hal. 51 
Untuk pembacaan terhadap prasasti dilakukan secara sekunder, yakni pembacaan melalui foto. Berdasarkan foto OD 2194 dapat diketahui bahwa kondisi prasasti ini sangat baik dengan huruf masih dapat dibaca dengan jelas. ${ }^{2}$ Ukuran fisiknya, panjang $37,5 \mathrm{~cm}$ dan lebar $17 \mathrm{~cm},{ }^{3}$ terdiri dari 36 baris tulisan beraksara Jawa Kuna dengan bahasa Sanskerta. Prasasti Cebongan tidak diawali dengan pertanggalan, sehingga pertanggalan hanya diduga secara relatif yakni melalui gaya aksara. Perkiraan sementara untuk pertanggalan prasasti ini adalah antara abad VIII akhir hingga abad IX awal. Aksara yang dituliskan relatif tegak dan bulat. Ciri aksara semacam ini berbeda dari aksara-aksara dari masa Kayuwangi-Balitung yang ramping dan sedikit miring ke kanan.

Bahasa yang digunakan di dalam prasasti Cebongan adalah bahasa Sanskerta. Pada beberapa baris tersisip sejumlah kosakata Jawa Kuna. Namun terlihat bahwa di dalam prasasti ini bahasa yang digunakan bukanlah tipe bahasa Sanskerta baku yakni tidak menggunakan kaidah tata bahasa Sanskerta khususnya di dalam derivasi dan konjugasi kata berdasar jenis kata. ${ }^{4} \mathrm{Di}$ dalam prasasti ini kosakata bahasa Sanskerta sekadar disusun menjadi sebuah kalimat yang mempunyai makna, sebagaimana diinginkan penulisnya (citralekha).

Satu ciri yang menarik dari prasasti ini adalah tidak dijumpainya pengulangan fonem konsonan yang muncul setelah fonem / $\mathrm{r} /$, misalnya kata gargā, sanwca dan supraga. Pengulangan fonem konsonan yang muncul setelah fonem /r/ seringkali muncul di dalam gaya penulisan prasasti pada masa Jawa Tengah bahkan hingga masa Jawa Timur, meski hal ini bukanlah suatu hal yang konsisten diterapkan penulis prasasti karena lebih berkaitan dengan personal style seorang penulis prasasti. Berikut adalah alih bahasa prasasti Cebongan, ${ }^{5}$

Alih bahasa :

1. Inilah salam penghormatan (bagi) kemenangan Garga (yang telah) mencabut/menghilangkan (hingga) bersih tanpa noda (bagai) cahaya guntur

2. penghuni yang menguasai kegelapan yang terdalam, langit, aliran air (ombak), guntur. Salam penghormatan (bagi)

3. pemilik kesempurnaan yang datang dari langit, gunung-gunung serta dari kedalaman

4. kemaluan wanita, kemaluan wanita ri gam ga ri gam ga ri, berjalan, berjalan

2 Melalui pengolahan gambar dengan program Adobe Photoshop CS dengan beberapa kali pembesaran dan perbaikan, huruf di dalam foto prasasti Cebongan (OD 2194) dapat dikenali dan dibaca kembali secara sekunder (Lihat lampiran foto)

3 Eggebrecht,op.cit, hal. 30

4 Contoh prasasti yang menggunakan huruf Jawa Kuna dengan bahasa Sanskerta yang 'baku' antara lain prasasti Tryambakalingga dan prasasti Haralingga dari Situs Kraton Ratu Boko.

5 Untuk alih aksara lihat dalam lampiran 1

Berkala Arkeologi Tahun XXIX Edisi No. 1 / Mei 2009 
5. bergerak gubha dubha ${ }^{6}$ ke dalam kemaluan wanita, gubha datang dari dalam (dengan) tanpa noda

6. terbebas dari rasa, malu, (dipenuhi) kemenangan (serta) dibebaskan dari segala penderitaan (ketakutan)

7. gam ga bertarung ${ }^{7}$ ke dalam, siri, bercampur dengan ${ }^{8}$

8. pi ri pi ri ghiri ghiri bersama-sama

9. saling birahi, bersama-sama (menjadi) pemberi kehidupan

10. lindungi lindungi ketika Pariwara Satwisatwasca

11. wi ri wi ri wi ri meletakkan kebahagiaan yang dirindukan (diharapkan)

12. Śini Muri ${ }^{9}$ menyatukan

13. teratai (air) bersih yang mempunyai kemenangan

14. kemenangan, jayo..., kekuatan

15. milik bhaga gati ${ }^{10}$ ratu yang bermahkota

16. malradhari memakai perhiasan bercahaya dan bersih

17. berasal dari Bhagawatimah Cidyā Dewi yang memelihara

18. memelihara ketika Pariwara Satwasca semuanya

19. menyucikan yani hu ru hu ru lindung lindungi ketika

20. (sedang) tidak terlindungi, dalam bahaya dan kehancuran

21. (dari) ketakutan. Jagalah, bebaskan jasad

22. oh! Teruskan, lanjutkan dengan bersama-sama dengan sepenuh tenaga hingga om menjadi sesuatu berbentuk candi candi

23. keburukan orang kikir (dengan) harta kekayaan, kemenangan bagi yang telah memimpin dan menghancurkannya tu ru hu ru

24. paduan (antara) daging dan air (sebagai) pemberian yang menyenangkan

25. pemberian dari Saba Dewāśana berupa kebijaksanaan yang merata

26. berbicara, prare, bernafas, mempunyai banyak anak ${ }^{11}$

27. semua mensucikan Dhara, Dhara, Dharani

28. Dhare, Dhare, anak laki-laki munu sumu sumu

29. pu mu wu mu ru ru ru ru

30. berasal dari luka tercela pada tubuh yang indah... (terjemahan masih sangat belum memuaskan)...

31. kemenangan, rusaknya pemberian/anugerah air (hujan?)

32. ... i je om para penduduk bumi ${ }^{12}$, istri istri

33. sesuatu untuk mensucikan ...(kata-kata sukar diurai secara etimologis)... untuk bisa terbiasa ${ }^{13}$ memberikan $^{14}$ sejumlah hasil panen ${ }^{15}$ setiap (musim)

Kata gubha dubha sukar untuk diuraikan secara etimologis

Samgara 'bertarung, bertempur, berperang'

Miri mungkin berasal dari kata miśri 'bercampur dengan'

Merupakan nama diri. Muri > Mura 'salah seorang Daitya Wisnu'

10 Ada beberapa kemungkinan dari kata ini. Kata bhaga 'nama salah seorang Aditya yang membawa kesejahteraan/kemakmuran, cinta dalam perkawinan', dan gati 'rahasia'. Atau merupakan kesalahan penulisan dari bhagatti 'pemberi keberuntungan'

11 Supraga > supraja 'mempunyai banyak anak'

12 Wasuddhe 'kerajaan, bumi, negara'

13 Taśila > tācchīlaya 'kebiasaan'

Berkala Arkeologi Tahun XXIX Edisi NNo. 1 / Mei 2009 
34. ... (kata-kata sukar diurai secara etimologis)... penyucian dengan api $\mathrm{api}^{16} \ldots$

35. ... (kata-kata bercampur dengan bahasa Jawa Kuna)... semua makhluk hidup bisa menyeberangi penderitaan, melawan lapar dan lelah dengan sebenar-benarnya

36. rusak rusak takut takut bunuh bunuh hancur hancur berbagai macam bencana hancur

\section{WANITA, BAYI DAN PEMUJAAN KESUBURAN}

Figur wanita menggendong bayi yang digambarkan di dalam prasasti Cebongan oleh Eggebrecht (1995) dan Scheurleer (1988) diidentifikasikan sebagai seorang Dewi Budhis yakni Hariti. Hariti adalah seorang yaksi yang sering digambarkan sebagai dewi kesuburan sekaligus penjaga anak-anak dari bala penyakit (Klokke, 1993: 127). Di dalam mitologi Budhis, Hariti pada mulanya adalah salah seorang yaksi yang mempunyai penyakit cacar dan sering memangsa anak-anak, tetapi oleh Budha diubah hidupnya, dan ditasbihkan sebagai dewi kesuburan dan kelahiran (Sahai, 1975: 253). Di dalam kisah yang lain, sebelum sebagai penganut Budha, Hariti gemar melakukan pesta menyantap daging anak-anak di Rajagriha. Kemudian penduduk Rajagriha meminta Budha untuk melindungi anakanaknya. Budha kemudian membawa anak termuda Hariti yang bernama Priyankara, kemudian dibawa ke tempat yang jauh. Hariti mencari anaknya tersebut ke berbagai tempat, akhirnya ia datang kepada Budha untuk meminta kembali anaknya. Budha mau mengembalikan anaknya dengan persyaratan Hariti bertobat, dan bersedia mengikuti ajaran Budha. Akhirnya Hariti menjadi pemeluk agama Budha, dan dikenal sebagai Dewi Ibu dan Dewi Kesuburan (Gupte, 1972: 119).

Di dalam perwujudannya pada relief candi, figur Hariti selalu dikelilingi oleh sejumlah anak-anak yang berada di sekitarnya ataupun di atas pangkuannya. Relief Hariti dijumpai pada Candi Banyunibo dan Candi Mendut. Relief Hariti di Candi Mendut merupakan relief yang sangat bagus menggambarkan ciri ikonografis Hariti. Relief Hariti di Candi Banyunibo dalam kondisi tidak utuh hanya menampakkan sejumlah anak-anak yang memanjat pohon.

\footnotetext{
14 Bamanta > vānta 'mengeluarkan, memberikan'

15 Res > riś 'panen, memotong padi'

16 Sudhe jwala 'penyucian dengan api'
}

Berkala Arkeologi Tahun XXIX Edisi JNo. 1 / Mei 2009 


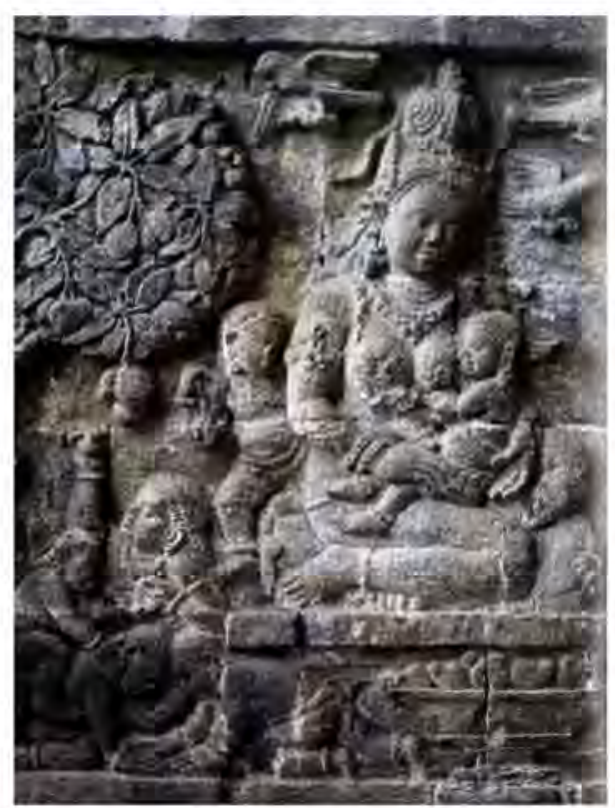

Foto 4.

Relief Hariti Candi Mendut (Sumber: Frederic, 1995)

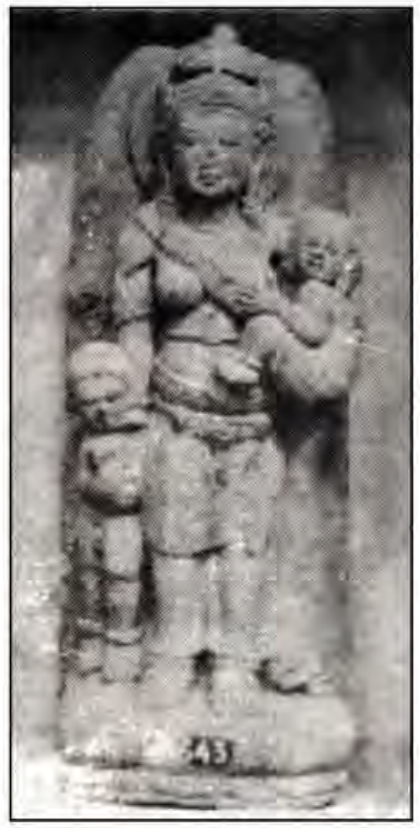

Foto 5

Arca Hariti museum Trowulan No.Inventaris 643 (Repro. Triharyantoro) Sumber: Berkala Arkeologi IX(1),1988

Hariti pada relief di candi Mendut digambarkan secara ikonografis memakai jatamakuta serta perhiasan-perhiasan di lengan, dan pergelangan tangan, serta kalung, dengan posisi duduk kaki bersimpuh. Selain itu pada koleksi Museum Mojokerto dijumpai arca Hariti dalam posisi berdiri, samabhangga, di atas lapik padma. Tangan kirinya menggendong seorang anak dalam kain gendongan dan di sisi kanannya terdapat seorang anak yang berdiri. Atribut yang tampak pada arca Hariti yakni memakai jatamakuta, kundala, hara, keyura, kankana, kucabandha,udharabandha dengan kain tipis berlipat-lipat hingga pergelangan kaki (Triharyantoro, 1988: 19).

Namun figur wanita yang digambarkan di dalam prasasti Cebongan jelas sekali bukan menunjukkan figur Hariti. Karena prasasti Cebongan adalah prasasti yang bercorak Hinduistis, yakni terlihat pada penyebutan Garga sebagai salah seorang wasu dalam Hindu. Figur tersebut juga tidak menampakkan ciri ikonografis sebagai seorang dewi, yang biasa tampak dalam mudra, sirascakra atau atribut-atribut arca lain.

Figur wanita dalam prasasti Cebongan berdiri dengan posisi tubuh tribhangga di atas sebuah lapik berbentuk persegi. Secara keseluruhan tidak terdapat atribut-atribut berupa perhiasan yang dipakai, terkecuali mengenakan mahkota bukan logam melainkan rangkaian bulu (?) sebanyak enam helai. Figur hanya digambarkan memakai kain bawahan yang tampak 
sangat tipis hampir seperti kulit. Keberadaan kain terlihat pada lipatanlipatan serta bagian tepiannya yang bergelombang. Figur wanita ini juga digambarkan memakai hiasan perut (udharabandha), sedangkan bayi yang berada di dalam gendongan tampak terbungkus dalam kain lampin yang hanya menampakkan bagian wajahnya saja.

Tubuh bayi ini ditopang oleh tangan kiri figur wanita, dan di atas tubuh bayi tampak tangan kanan figur wanita diletakkan di atasnya. Bayi ini digambarkan berada di dalam kain gendongan yang diikat simpul pada bahu kanan figur wanita. Identifikasi figur wanita yang menggendong bayi ini tampaknya mengacu pada penyebutan seorang tokoh wanita yang disebut di dalam prasasti, yakni pada baris 15 hingga 17:

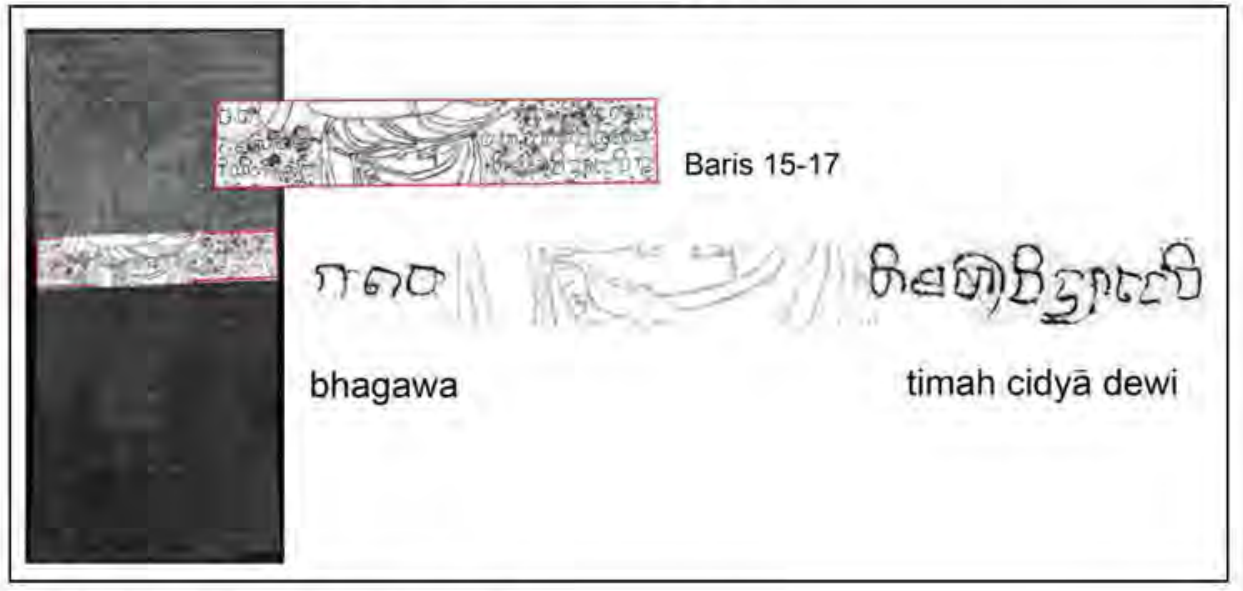

(15). wati bhaga gati ratumaku

(16). ta malradhari wahawidha cicitra wemala

(17). rini bhagawatimah cidyā dewi raksa

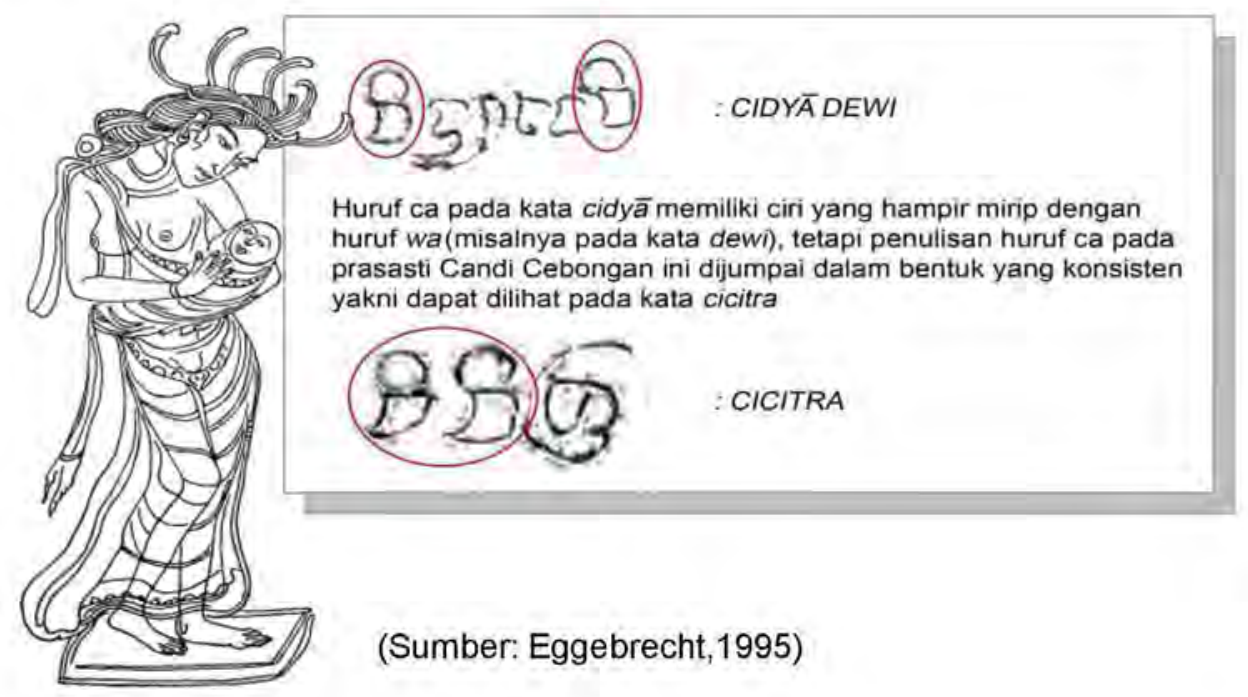


Secara bebas dapat diartikan "...ratu (ber)mahkota malradhari memakai perhiasan bercahaya ${ }^{17}$ (dan) bersih, dari bhagawatimah cidyā dewi ...". Kata 'ratumakuta' inilah yang memperkuat dugaan bahwa wanita menggendong bayi tersebut adalah Bhagawatimah Cidyā Dewi, karena dijumpai adanya kesesuaian antara penyebutan di dalam prasasti dengan penggambaran secara piktorial di dalam prasasti.

Apabila diuraikan secara etimologis frase ratumakuta merupakan bentuk hibrid antara kata Jawa Kuna ratu "raja wanita", dan kata dalam bahasa Sanskerta mukuta "mahkota", sedangkan kata malradhari tampaknya sukar diuraikan secara etimologis. ${ }^{18}$ Maka dapat diketahui bahwa figur wanita yang digoreskan di dalam prasasti Cebongan adalah Bhagawatimah Cidyā Dewi, yang digambarkan sebagai ratu bermahkota malradhari (atau 'memakai rangkaian bunga berbentuk lingkaran?').

Kata bhagawatimah secara etimologis dapat dikaitkan dengan kata bhagawatī yang bermakna feminin 'the Lady', tetapi secara lebih spesifik kata bhagawatī merupakan nama lain dari Pārwatī (Liebert, 1976).

Hanya sejauh itu informasi yang diberikan prasasti mengenai identifikasi figur wanita menggendong bayi tersebut. Apakah ia sebagai dewi 'celestial body', atau makhluk semi-dewa belum dapat diberi jawaban yang memuaskan. Hal ini disebabkan karena figur wanita ini tidak memiliki penanda-penanda khusus atau atribut-atribut yang dapat dipakai sebagai pengidentifikasian status 'kedewiannya'. Belum lagi nama Bhagawatimah Cidyā Dewi tidak dijumpai dalam jajaran nama-nama dewa Hindu, bahkan dewa minor sekalipun. Pada baris ke-25 prasasti Cebongan disebutkan kata Saba Dewāśana 'Istana Dewa', agaknya Bhagawatimah Cidyā Dewi termasuk salah satu penghuni Saba (Sabha) Dewāśana tersebut.

Informasi lain yang secara eksplisit dapat dikaitkan dengan tokoh wanita yang disebut di dalam prasasti Cebongan ini terlihat pada baris 7 dan 27 ,

(7) ... gam ga samgarani siri siri miri mi ...

(27) ...ppawisodhani dhara dhara dharani ...

Pada baris 7 tersebut dijumpai kata siri yang pada dasarnya merupakan aspek ibu dari Dewi Sri (Sahai, 1975: 165), sedangkan pada baris 27 dijumpai kata dhara yang secara harafiah bermakna 'memakai, memegang'. Tetapi kata ini dapat juga berarti 'nama salah seorang Wasu'. Wasu itu sendiri merupakan kelompok dewa ataupun makhluk semi-dewa berjumlah 8 yang merupakan pengikut Indra (Liebert, 1976: 332). Menariknya, pada pembukaan prasasti Cebongan ini penghormatan juga ditujukan kepada salah seorang Wasu yakni Gargā.

Pada masa Jawa Kuna, Gargā tidak ditempatkan sebagai dewa utama di dalam prasasti. la sering muncul pada bagian persumpahan yang

17 Cicitra di dalam bahasa Jawa Kuna bermakna "digambarkan, dilukiskan, dengan lukisan", sedangkan kata citra di dalam bahasa sanskerta bermakna "bersih, intan, terang, bercahaya".

18 Mungkinkah kata malradhari berasal dari kata mala "rangkaian bunga berbentuk lingkaran", dan kata dhara "memakai"

Berkala Arkeologi Tahun XXIX Edisi $\mathcal{N}$ No. 1 / Mei 2009 
disebutkan bersamaan dengan 'celestial body atau Hyang' lain seperti Kusika, Metri, Kurusya, dan Patanjala. Mereka ditempatkan sebagai saksi dan pemberi hukuman kepada setiap orang yang melanggar ketentuan sebagaimana dicantumkan dalam prasasti Rukam.

... an andah ta kamun hyan kusiga gargga metrī kurupya pātāñjala suwuk lor kidul kulwan waitan buannakan in

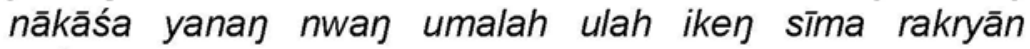
sañjiwana de... (Prasasti Rukam lempeng II baris17)

Semua nama tersebut dijumpai di dalam persumpahan prasasti Rukam (907 Masehi). Menurut Bhandarkar (1913) sebagaimana dikutip oleh Nastiti (1982) kelimanya merupakan makhluk mistis dari para lakulin yakni para Brahmana sebagai inkarnasi Wasudewa. Adapun Farquhar (1967) mengidentifikasi kelimanya sebagai murid Wasudewa yang mengajarkan pasupata (Nastiti dan Dyah Wijaya Dewi, 1982: 53).

Menurut Goris di dalam ajaran Pasupata, Siwa memiliki lima pengikut yakni Kuśika, Gārgya, Mitra, Kaurusya, dan Patañjala. Di dalam tulisan-tulisan Bali kelima pengikut ini muncul di bawah nama-nama Pañca Kośika (Goris, 1974: 15). Prasasti Rukam menunjukkan bahwa kelima tokoh tersebut diberi partikel penyebutan dengan kata hyang, atau hanya berwujud makhluk semi-dewa. Dalam prasasti Cebongan, kemungkinan keberadaan para makhluk semi-dewa ini dapat diidentifikasikan dalam penyebutan para penghuni yang menguasai kegelapan, langit, aliran air, guntur, serta datang dari gunung-gunung dan kedalaman gabha (vulva).

Pada baris 27 tersebut juga dijumpai kata dharani yang merupakan nama istri Paraśurama sekaligus personifikasi bumi yang dikaitkan dengan awatara Laksmi (Liebert, 1976). Selain itu dijumpai pula bahwa dharani dhara merupakan gelar kepahlawanan Kresna atau juga Wisnu (Mac Donnel, 1954). Sampai di sini terlihat bahwa prasasti Cebongan banyak mengindikasikan aliran Waisnawa-Pasupata, yakni keberadaan para wasu, serta aspek sakti Wisnu yang berwujud Laksmi dan Sri. ${ }^{19}$ Menurut Goris (1974), Hinduisme di Jawa antara tahun 200-700 Masehi hampir memiliki kesamaan dengan kondisi di India yakni hanya dikenal 2 kelompok besar, yakni kelompok Śiwais dan kelompok Śakta. Kelompok Śiwais terdiri dari kelompok-kelompok ortodoks (Smārta), Waisnawa - Pasupata, dan Siddhanta (Agama). Sedangkan kelompok kedua adalah para Sakta yang

19 Aliran waisnawa juga teridentifikasi dari keberadaan prasasti Plalangan yang memuat relief manusia memanah sebagai awatara dewa Wisnu sebagai Rama (Setyastuti dan Rita Margaretha,1994:214). Selain itu artefak berupa arca yang berkaitan dengan dewa Wisnu cukup banyak ditemukan di wilayah Yogyakarta, seperti fragmen arca (BG 265) setinggi $80 \mathrm{~cm}$ yang menampakkan seekor Garuda dalam posisi tergolek melingkari kaki seorang figur dewa yang berdiri. Sedangkan arca yang menampakkan awatara Wisnu adalah arca Wisnutriwikrama dan Narasimha, keduanya ditemukan di Situs Sumur Bandung. Untuk bangunan candi yang dapat dikaitkan dengan pemujaan Wisnu adalah Candi Barong. 
memuja Durga dalam bentuk bhairawa, juga pemujaan khusus terhadap Sūrya dan Ganeśa (Ganapati) (Goris, 1974: 11).

Di India secara lebih spesifik pada abad 5 hingga 6 Masehi yakni pada masa Gupta untuk pertama kalinya ditemukan prasasti yang mengindikasikan Waisnawa. Setidaknya terdapat 6 buah prasasti yang mengindikasikan persatuan Sri-Laksmi dengan Wisnu. Salah satunya adalah prasasti Aphsad yang menyebutkan Sri sebagai istri dari Wasudewa (Sahai, 1975: 173). Pada masa selanjutnya, setelah abad 9 atau ke-10 Masehi di dalam agama Hindu jumlah sekte semakin bertambah, bahkan berkembang menjadi beberapa sub-sekte. Sekte Waisnawa terpecah menjadi Bhāgawata dan Pāñcaratra dengan sejumlah sub-sekte seperti Madhwa, Wisnuswami, Nimbarka, Sri Waisnawa, Manbhau, Narasingha, dan Rama. Demikian pula Siwaisme juga terpecah menjadi kelompok Pasupata, dan Siddhanta. Masing-masing juga memiliki sejumlah sub-sekte yang cukup banyak (Goris, 1974: 10).

Penyebutan sejumlah figur yang mengindikasikan feminine deity, yakni Sri dan Laksmi meski hanya dituliskan dalam aspeknya berupa Siri dan Dharani semakin memperkuat dugaan bahwa prasasti Cebongan ini berkaitan erat dengan kesuburan. Dijumpainya kata kamale (baris 31 ) yang berarti 'bunga teratai' merupakan simbol air dan kesuburan (Sahai, 1975: 161). Seringkali feminine deity digambarkan memiliki atribut atau juga wahana yang sama dengan atribut yang dimiliki masculine deity yang menjadi sakti-nya. Hal yang sama juga berlaku pada sapta-matrka. ${ }^{20} \mathrm{Di}$ dalam prasasti Cebongan ini tampak bahwa Bhagawatimah Cidyā Dewi tidak memiliki atribut apapun yang dapat mencitrakan ia sebagai aspek SriLaksmi, bahkan hingga saat ini di Indonesia belum dijumpai penggambaran Sri atau Laksmi yang menggendong bayi. Penggambaran feminine deity dengan bayi justru dijumpai dalam sapta matrka, meski di dalam kasus yang cukup jarang. Para sapta matrka ini digambarkan dengan seorang anak di salah satu lengannya. Relief dari masa Kusana menggambarkan tiga matrka masing-masing dengan seorang anak. Akan tetapi sebagai catatan, meski masing-masing membawa anak namun tetap dicirikan dengan wahana yang merupakan penanda khusus sakti dari salah seorang masculine deity (Sahai, 1975: 209).

Hipotesis sementara yang dapat diambil mengenai pribadi Bhagawatimah Cidyā Dewi adalah: ia seorang makhluk semi-dewa 'lokal' yang dipuja sebagai fertility image, di samping telah ada figur lain yang lebih populer di masa Jawa Kuna yakni Hariti. Mengenai kepercayaan 'makhluk lokal' yang muncul di dalam prasasti, juga pernah diidentifikasikan oleh Sedyawati (1983) yang membandingkan antara makna kata asli secara etimologis (baca: bahasa Sanskerta) dengan makna yang muncul dalam

20 Sapta matrka atau tujuh ibu merupakan representasi sakti para dewa penting yakni Brahmani (Saraswati), Maheswari (Raudri), Kaumari (Karttikeyani), Waisnawi (Laksmi), Varahi, Indrani (Mahendri) dan Chamunda (Chamundi). Jumlah dari dewa ibu ini sering disebut berjumlah tujuh, delapan atau bahkan lebih (Sahai, 1975: 207). 
bahasa Jawa Kuna, khususnya dalam hal penyebutan makhluk gaib dalam sebuah sapata prasasti (Sedyawati, 1983: 25).

Pemujaan terhadap kesuburan juga dikenal di wilayah Asia seperti India, China, Jepang dan Tibet. Keseluruhan dari objek pemujaan tersebut memiliki ciri yang sama, yakni penggambaran bayi di dalam gendongan, pangkuan, ataupun anak-anak di sekelilingnya.

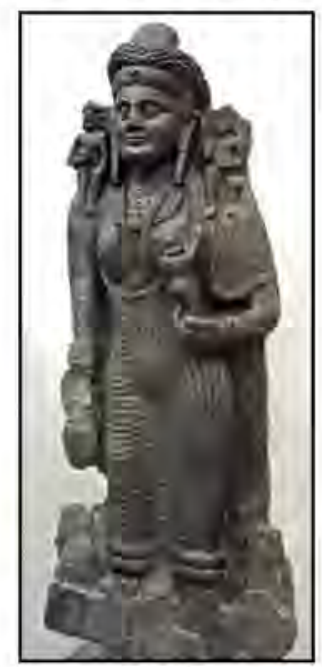

Foto 6

Arca Hariti dari India Utara, Chandigarh (sumber: www. shunya.net)

Namun umumnya dewi-dewi yang dipuja tersebut merupakan aspek lain dewi-dewi yang umum dikenal, seperti pemujaan terhadap Juntei Kannon Bosatsu di Jepang yang merupakan aspek lain dari Awalokiteswara. Pemujaan terhadap figur ini bertujuan sebagai dewi pelindung proses kelahiran sekaligus pelindungan terhadap anak-anak. Selain itu juga terdapat aspek Awalokiteswara yang lain yang juga dipuja di Jepang yakni Koyasu Kannon yang merupakan dewi pelindung anak-anak yang populer di Jepang pada abad ke-8 Masehi (Frederic, 1995: 178-179).
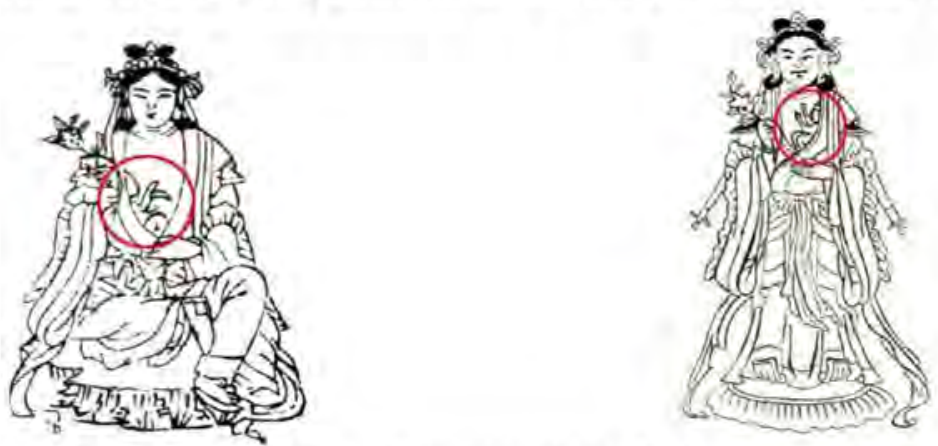

Figur wanita menggendong bayi

Karitei-mo (kiri) dan Kishimojin (kanan).Keduanya merupakan aspek dari Awalokiteswara yang populer di Jepang pada periode Kamakura

(Frederic, 1995:179) 


\section{SEBUAH MANTRA FERTILITAS}

Di dalam prasasti ini disebut beberapa pariwara, mungkin sebagai pengiring Bhagawatimah Cidyā Dewi. Bermula dari para pariwara tersebut, secara eksplisit diperoleh gambaran alam pikir manusia Jawa Kuna mengenai 'perkembangan embriologis' sesuai anggapan pada masanya. Proses tersebut dapat dirangkum menjadi 5 fase yakni :

Fase pertama : Proses persetubuhan yakni percampuran antara dua mani. Pariwara yang bertugas melindungi adalah Pariwara Satwisatwasca.

Fase kedua : Proses penyatuan dengan pelindung Sini Muri (?)

Fase ketiga : Masa ketika Bhagawatimah Cidya Dewi memberikan anugerah berupa bayi sempurna (di dalam rahim?) sekaligus melindunginya hingga tahap berikutnya.

Fase keempat : Proses 'pembebasan jasad' (baris 21) atau proses kelahiran yang dianggap sebagai masa yang tak terlindungi (anatha) dalam bahaya (natra), dan kehancuran serta ketakutan.

Fase kelima : Fase bayi sempurna yang telah dilahirkan yang merupakan 'paduan daging dan air sebagai pemberian yang menyenangkan'.

Keseluruhan fase-fase tersebut diakhiri dengan proses kelahiran bayi sempurna. Selanjutnya prasasti menyebutkan sebuah seruan yakni di baris ke-22 (dimungkinkan sekali teruntuk bagi orang tua yang telah terkabul keinginannya) agar bersama-sama membuat sebuah 'candi' dengan penuh semangat. Kata 'cañdi' di dalam prasasti Jawa Kuna setidaknya diketahui di dalam dua buah prasasti yakni prasasti Ngabean (OJO CVI) ... pacandyan i kwak ... serta dalam prasasti Paguyangan ... candi i burwan (Soekmono, 1978: 288). Kata 'candi' di dalam prasasti Cebongan ini secara implisit tidak diikuti dengan sebuah nama lokasi sebagaimana dua buah prasasti di atas. Apakah kata 'candi' dalam prasasti Cebongan dapat dianalogikan dengan pelinggih taksu di Bali, karena dijumpai sebuah kasus yang mirip.

Dalam lontar Anggatya Bana disebutkan bahwa pelinggih taksu didirikan untuk mengingat nyama pat atau 'empat saudara'. Diceritakan bahwa semasa masih di dalam kandungan, janin dilindungi Bhatara Siwa. Kemudian sang janin diminta untuk menjelma ke dunia karena ia tidak bisa selamanya tinggal di dalam kandungan. Akan tetapi, sang janin merasa takut karena di dunia penuh dengan gangguan dan marabahaya. Kemudian Bhatara Siwa berjanji bahwa sang janin akan tetap aman terlindungi asalkan ia meminta tolong kepada keempat saudaranya (nyama pat) yakni ari-ari, darah, air ketuban dan lamas. Sejak lahir, nyama pat tersebut sudah disembahyangi oleh orang tuanya dengan segehan kepel (Acwin, 2008: 108-109). Adapun segehan kepel ini berupa sesajian yang ditempatkan 
dalam sebuah wadah kecil yang diisi dengan nasi, bawang merah, garam yang diletakkan di empat penjuru angin dan di tengah-tengah. ${ }^{21}$

Inti pokok dari seluruh teks prasasti Cebongan adalah sebuah mantra. ${ }^{22}$ Mantra secara etimologis berarti formula magis atau silabel mistis. Mantra terdiri dari sejumlah silabel yang kadang memiliki suatu makna yang digunakan dalam upacara sebagai sarana pembebasan. Mantra mempunyai dua tipe yakni kanţhika merupakan mantra yang disuarakan dengan keras, tipe kedua adalah ajapa yang merupakan mantra tidak diucapkan. Mantra yang dituliskan dapat dianggap sebagai manifestasi dari dewa yang disebutkan (Liebert, 1976: 171).

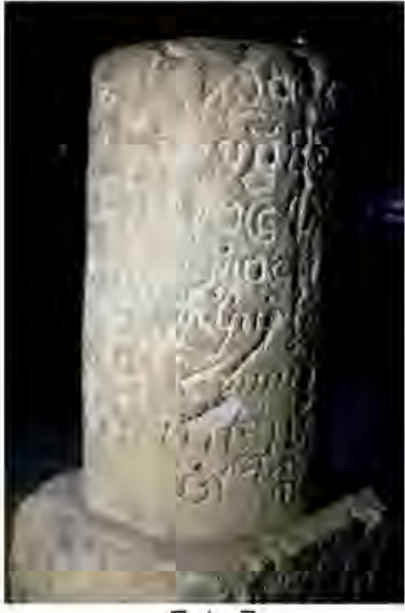

Foto 7.

Prasasti Jragung

(Sumber: Do. BP3 Yogyakarta)

Sejauh ini prasasti berisi mantra lebih banyak ditemukan sebagai isian peripih bangunan candi. Wujudnya sering dalam bentuk lembaran emas tipis, seperti dijumpai dalam peripih dari Candi Garuda kompleks Candi Prambanan yang berisi nama-nama dewa mata angin. Selain itu juga dijumpai dalam bentuk lembaran emas tipis yang digulung seperti temuan dari Candi Barong, Sambisari, dan Situs Kraton Ratu Boko. Mantra juga ditemukan sebagai prasasti berbentuk lingga seperti di dalam prasasti Jragung. ${ }^{23}$

Kesamaan dari prasasti-prasasti mantra tersebut adalah terdapatnya silabel-silabel mantra yang merupakan bijamantra (Liebert, 1976: 41). Bijamantra merupakan jenis silabel seruan yang menyimbolkan manifestasi singkat

dari bentuk dewa. ${ }^{24}$

Di dalam prasasti Cebongan silabel mantra yang dijumpai antara lain om, gam, hu dan ru. Gam adalah bijamantra yang menyimbolkan Ganesa. Ganesa juga direpresentasikan dengan bijamantra om (aum), gam dan glaum (Liebert, 1976: 88-90). Selain itu ada beberapa silabel mantra yang tidak diketahui maknanya yakni miri, piri, ghiri, $t u, c u, p u$, munu dan sumu.

21 Informasi dari Ni Luh Nyoman Rarianingsih

22 Prasasti-prasasti panjang dari masa Jawa Kuna dapat dikategorikan menjadi 3 berdasar isinya yakni prasasti penetapan sima, prasasti keputusan hukum (jayapatra) dan prasasti mantra. Untuk kategori prasasti sima dan jayapatra memiliki struktur yang 'baku' baik dalam isi maupun segi kebahasaannya. Sedangkan prasasti kategori mantra masih jarang penelitian tentangnya. Pengklasifikasiannya baru sebatas pada indikator-indikator kehadiran silabel mantra.

23. Untuk lebih lengkap dapat dilihat dalam 'Pusaka Aksara Yogyakarta : Alih Bahasa dan Alih Aksara Prasasti-Prasasti Koleksi Balai Pelestarian Peninggalan Purbakala Yogyakarta', BP3 Yogyakarta, 2007

24 Beberapa bentuk mantra adalah brahmabija, văgbija, māyābija, lakșmībija, kãmabija dan ādyabija 
Silabel-silabel semacam itu merupakan sebuah 'seruan suci' yang menempati posisi tertinggi di dalam ritual pemujaan. Di dalam Bhuwana Kośa tata urutan ritual dari tingkatan yang paling rendah ke tingkat tertinggi adalah sebagai berikut

- Arcana (upacara agama)

- Mudrā (sikap tangan)

- Mantra

- Kutamantra (mantra utama)

- Pranawa (suku kata suci yakni om) ((Goris, 1974: 14).

Dugaan sebagai sebuah prasasti mantra juga diperkuat di dalam pembukaan prasasti Cebongan yang tidak diawali dengan pertanggalan sebagaimana umumnya prasasti Jawa Kuna, tetapi justru menyeru penghormatan bagi Gargā, seorang wasu yang biasa disebut di dalam sapata prasasti.

\section{PENUTUP}

Prasasti Cebongan adalah sebuah prasasti mantra, khususnya mantra fertilitas pengharapan akan anak dengan fertility image Bhagawatimah Cidyā Dewi yang digambarkan menggendong bayi. la tentu mempunyai korelasi yang erat dengan aliran Waisnawa-Pasupata yang pernah hadir di Jawa abad 9 Masehi. Bhagawatimah Cidyā Dewi adalah makhluk semi-dewa 'lokal' yang menjadi objek pemujaan bagi kesuburan. Semoga makalah ini dapat memberi sumbangan bagi penelitian mengenai eksistensi prasasti-prasasti mantra yang belum banyak penelitian tentangnya, sekaligus eksistensi makhluk gaib 'lokal' yang tentunya pernah hidup sebagai ikon pemujaan.

Sukoharjo, akhir Maret 2008 Nahān hīngan iking kathā wiwakşan 


\section{KEPUSTAKAAN}

Acwin Dwijendra, Ngakan Ketut, 2008, Arsitektur Bangunan Suci Hindu Berdasarkan Asta Kosala Kosali, Denpasar:Udayana University Press

Balai Pelestarian Peninggalan Purbakala Yogyakarta, 2007, Pusaka Aksara Yogyakarta, Alih Aksara dan Alih Bahasa Prasasti Koleksi Balai Pelestarian Peninggalan Purbakala Yogyakarta, Yogyakarta : BP3 Yogyakarta

Djafar, Hasan, 2000, 'Tradisi Tulis : Bibliografi Deskriptif Beberapa Sumber Rujukan Untuk Studi Epigrafi' dalam Kajian IImiah Temuan Satu Abad (1900-1999), Jakarta : Museum Nasional

Dwiyanto, Djoko, 1993, 'Metode Penelitian Epigrafi Dalam Arkeologi', dalam Artefak No. 13 Agustus, HIMA, Yogyakarta : Fakultas Sastra Universitas Gadjah Mada

Eggebrecht, Arne und Eva, 1995, Versun Kene Konigreische Indonesians, Meinz : Verlag Phillip von Zebern

Frederic, Louis, 1995, Buddhism : Flammarion Iconographic Guides, Paris : Flammarion

Gupte, R.S, 1972, Iconography of The Hindus Buddhist and Jains, Bombay : DB. Taraporevala and Private Ltd.

Goris, R, 1974, Sekte-Sekte di Bali, Jakarta:Bhratara

Klokke, Marijke J., 1993, The Tantri Relief on Ancient Javanese Candi, Leiden : KITLV Press

Liebert, Gösta, 1976, Iconographic Dictionary of The Indian Religions, Hinduism-Buddhism-Jainism, Leiden : E.J. Brill

Mac Donnel, Arthur Anthony, 1954, Sanskrit Dictionary, London : Oxford University Press

Nastiti, Titi Surti dan Dyah Wijaya Dewi, 1982, Tiga Prasasti Dari Masa Balitung, Jakarta : Pusat Penelitian Arkeologi Nasional, Departemen Pendidikan dan Kebudayaan

Sahai, Bhagawant, 1975, Iconography of Minor Hindu and Buddhist Deities, New Delhi : Abhinav Publications 
Scheurleer, Pauline Lunsingh and Marijke J. Klokke, 1988, Divine Bronze : Ancient Indonesian Bronzes From AD 600-1600, Leiden : E.J. Brill

Sedyawati, Edi, 1983, 'Kemungkinan Prasasti Sebagai Sumber Data Ikonologi' dalam Berkala Arkeologi IV(2) September, Yogyakarta : Balai Arkeologi Yogyakarta

Setyastuti, Ari dan Rita Margaretha, 1994, 'Prasasti Plalangan : Data Waisnawa di Jawa', dalam Berkala Arkeologi Edisi Khusus, Yogyakarta : Balai Arkeologi Yogyakarta

Soekmono, 1978, Candi Fungsi dan Pengertiannya, Disertasi, Jakarta : Fakultas Sastra Universitas Indonesia

Triharyantoro, Edi, 1988, 'Pemujaan Hariti di Trowulan', dalam Berkala Arkeologi IX(1), Yogyakarta : Balai Arkeologi Yogyakarta

Zoetmulder, P.J, 1997, Kamus Jawa Kuna - Indonesia, Jakarta : PT. Gramedia Pustaka Utama

\section{Ucapan terima kasih :}

Makalah ini tidak terwujud apabila tanpa bantuan dari sejumlah pihak. Kepada Drs. Tjahjono Prasodjo, M.A diucapkan terimakasih atas bantuan literatur yang pada akhirnya bisa menjadi langkah awal untuk melacak kembali Sang Bhagawatimah Cidya Dewi dari Cebongan ini. 


\section{LAMPIRAN 1}

Alih aksara prasasti Cebongan

1. // tad yathā oṃ wimula gargā wimula wimale jaya gargā wajra jwalaga

2. bhreg gati gahane gagana wiśodhane sarbwap pawiśoyane om gu

3. nawati gaganawicāriṇi giri giri gama ri gama gama ri gaha gaha

4. bhreg ri gabbh ri gabha ri gabha ri gabha ri gam ga ri gam ga ri, gati gati, ga

5. ni gama re gubha dhubha (gga)bha ni gubha ni wale wimale mu

6. céle jaye wijayo sarba bhaya wigate

7. gam ga samgaraṇi siri siri miri mi

8. ri piri piri ghiri ghiri samga

9. ntā kamāni sawisatra prama( ...)( ...)

10. rakșa rakșa masa pariwara satwisatwa

11. śca, wiri wiri wiri dhādha raṇi wena

12. śini muri ma(...) mili mili, ka

13. male wimale jaye wi

14. jaye jayo (...) tejayā

15. wati bhaga gati ratumaku

16. ta malradhari wahawidha cicitra wema(la)

17. rini, bhagawatimah cidyā dewi rakṣa

18. rakșa masa pariwara satwaśca samantāt parbat

19. pawino (ya)ni hu ru hu ru, rakșa rakṣa māsa

20. pariwara sarwca satwaśca anāthā natrā ṇasa pa

21. bhayaṇa niśarạ̣ān parimocaya saba

22. duh legya ca om candi candi ni wegawatī sarda

23. duṣpani wāraṇi wijaya hahinī tu ru hu ru ma

24. ru mu cu ru cu ru ayumpalanī sara wara mathanì

25. saba dewaśaña swajite wi ri dhi ri samanta wada

26. 1 kite prare praña supraga wiśuddhe sa

27. rba ppawisodhani dhara dhara dharani

28. dhare dhare sunu munu sumu sumu

29. pu mu wu mu ru ru ru ru cale

30. talaya duṣpansā heśaśrī wapu

31. jaya kamale kșini kșini wara

32. (...) i je om wadwa wasuddhe gara gara giri giri kuru kuru ma i lawiśuddhe

33. (pa)(wi)tra mu(wai) lidga ni wedga nila rawe rajwali taśila resbamanta pranā

34. ri ta weñasita suddhe jwala jwala sarba (..)wa gana samā kapaṇi sitya(wa)

35. te ta(ra) tara tā yasa (ba) satwantā (śa)wirle kite lapālśa tuhu tuhu

36. turu turụ̣ ghirī ghirī hạ̣i haṇiḥ kṣaṇi kṣaṇi sarba prahara kṣiṇi

Keterangan :

(...) : satu karakter tidak terbaca

(ba) : satu karakter kurang jelas/bacaan masih meragukan 


\section{Lampiran 2}

Foto OD 2194 setelah disunting dengan Adobe Photoshop CS

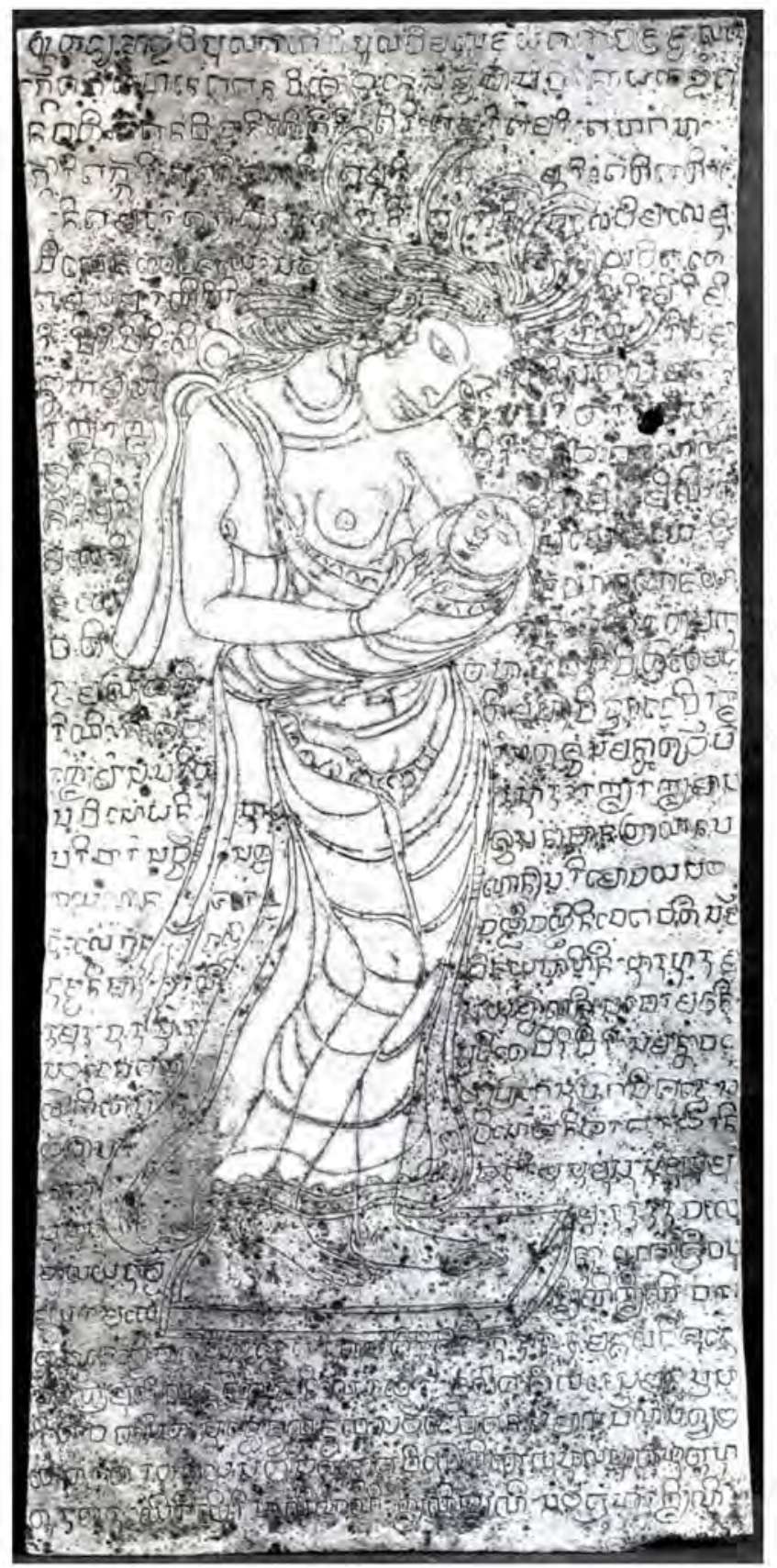

